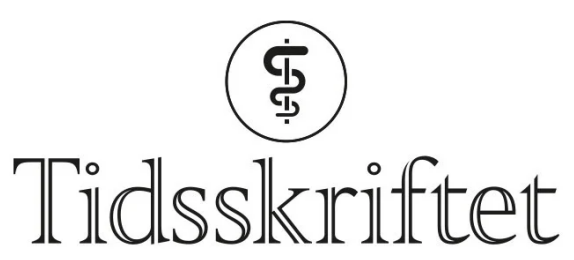

DEN NORSKE LEGEFORENING

\title{
Urinundersøkelse gjennom tidene
}

\author{
MEDISINSK HISTORIE \\ JOSTEIN HALGUNSET \\ jostein.halgunset@ntnu.no \\ Institutt for klinisk og molekylær medisin \\ Norges teknisk-naturvitenskapelige universitet \\ Jostein Halgunset (f. 1951) er lege og professor i anatomi. \\ Forfatter har fylt ut ICMJE-skjemaet og oppgir ingen interessekonflikter.
}

\section{SVERRE MYREN-SVELSTAD}

Avdeling for nevrologi og klinisk nevrofysiologi

St. Olavs hospital

og

Institutt for nevromedisin og bevegelsesvitenskap

Norges teknisk-naturvitenskapelige universitet

Sverre Myren-Svelstad (f. 1986) er lege i spesialisering i nevrologi og stipendiat.

Forfatter har fylt ut ICMJE-skjemaet og oppgir ingen interessekonflikter.

\section{I mange hundre år var urinen ansett som den viktigste kilden til informasjon om prosesser i kroppens indre. I den humoralpatologiske tradisjonen var inspeksjon av urin, uroskopi, legenes viktigste diagnostiske verktøy. Dette endret seg med fremveksten av moderne fysikk, kjemi og medisin.}

Trusselen om sykdom har i de fleste kulturer vært oppfattet som skremmende. I mange tilfeller har dette ført til leting etter observerbare tegn som kan indikere en sykelig tilstand og forutsi dens forløp.

Tidlig oppsto ideen om at det som går inn i kroppen, slik som mat, drikke og luft, kunne være med på å forklare hvorfor sykdom oppstår. Samtidig kunne det som kommer ut av kroppen, slik som urin og avføring - og noen ganger blod - inneholde signaler om de indre prosessene, som ellers er skjult for direkte observasjon. Man oppdaget at ulike sykelige tilstander kan føre til endringer i vannlatingen og urinens utseende.

Det er uklart i hvilken utstrekning man i de tidligste mesopotamiske kulturene, Sumer og Babylonia, har foretatt en systematisk vurdering av urinen som ledd i medisinsk praksis. Men i British Museum finnes fragmenter av en ordsamling fra ca. år 4000 f.Kr., i kileskrift, der flere oppslag synes å henspille på urin med ulike farger, som «lys», «mørk» og «rød». 
Dette tyder på at de i hvert fall var klar over at urin kunne ha ulike kvaliteter som det var meningsfullt å klassifisere. I indisk medisin spilte unders $\emptyset$ kelse av urin en stor rolle, idet ulike typer unormal urin er beskrevet med stor systematikk i gamle sanskrittekster (1).

\section{Tidlig gresk medisin}

I den vestlige verden var humoralpatologisk medisin (latin humor = væske) rådende fra ca. 500 f.Kr. til slutten av 18oo-tallet. God helse var betinget av riktig balanse mellom de fire kroppsvæskene (kardinalvæskene) blod, slim, gul og svart galle, en biologisk parallell til de fire elementene luft, vann, ild og jord.

Kroppens normaltilstand var helse (eukrasi), mens sykdom ble oppfattet som uttrykk for ubalanse mellom kroppsvæskene (dyskrasi). Dette ble omtalt som kraselæren. Fenomener som feber, oppkast og svette var kroppens måte å kvitte seg med overflødig væske på. Dersom kroppen ikke selv klarte å gjenopprette balansen, måtte man ty til hjelpemidler som årelating, brekkmidler, avføringsmidler og hostestillende midler $(\underline{2}, 3)$.

Urinen ble ansett å bære med seg informasjon om tilstanden i kardinalvæskene, og et misforhold mellom væskene ville derfor finnes igjen som forandringer i urinen (4). Ved siden av anamnesen ble nøyaktig pulsundersøkelse og inspeksjon av urinen de to viktigste metodene til å bestemme sykdommens natur (diagnostikk) og å forutsi dens videre forløp (prognostikk).

Hippokrates (46o-377 f.Kr.) var sentral i den tidlige utviklingen av den humoralpatologiske medisinen. Han var først og fremst kliniker og la stor vekt på observasjon av alle sider ved sykdomsbildet. I dette inngikk inspeksjon av urinen som ett av flere elementer.

Leger av den hippokratiske skolen var opptatt av å fastlegge prognosen, det vil si finne de tegn som kunne tale for et heldig utfall eller de som innebar dystrere utsikter. De viste begrenset interesse for anatomi og fysiologi, og de prøvde ikke i særlig grad å teoretisere eller forklare de kliniske observasjonene ut fra bakenforliggende mekanismer. Hippokrates mente at urinen ble til i urinblæren og tilla ikke nyrene noen vesentlig rolle. Likevel er det angitt i de hippokratiske aforismer at dersom man observerer bobler i urinen, og særlig dersom urinen har et tykt lag med skum, så indikerer det sykdom i nyrene (5).

Galenos fra Pergamon (131-201 e.Kr.) forsøkte å konstruere et helhetlig medisinsk tankesystem, konsistent med Aristoteles' fysikk, og bidro med dette til systematisering av kraselæren. Likesom hos Hippokrates utgjorde urinundersøkelser en del av diagnostikken, særlig ved sykdom i urinveiene. Men legen skulle først og fremst basere sin vurdering på pasientens beskrivelse av sine nåværende og tidligere plager, livsførsel og vaner, sammenholdt med observasjon av pasientens kroppslige karakteristika, inklusive respirasjon, hudfarge, temperatur og en detaljert vurdering av pulsen (sfygmologi).

Galenos forestilte seg tre trinn i fordøyelsesprosessen - det første foregikk i magesekken, det andre i leveren og det tredje i blodårene, det vil si venene. Ved hvert trinn ble det skilt ut avfall. Det første trinnet resulterte i avføringen. Urin ble dannet ved leverfordøyelsen, som ellers hadde til hovedformål å produsere nytt blod. Det tredje trinnet var mer komplekst og resulterte i en rekke unyttige substanser, hvorav en del ble gjenfunnet som utfellinger i urinen ( $\underline{6}$ ). Etter Galenos' oppfatning sørget nyrene for å skille urinen fra blodet, og den ble deretter transportert til blæren via urinlederne (7.).

\section{Bysantinsk og salernitansk medisin}

I den bysantinske perioden (30o-tallet til 1453) bidro en rekke leger til den videre utviklingen av urinundersøkelsen, som nå ble kalt uroskopi. En av de første velrenommerte legene var Theophilus Protospatharius, som antas å ha levd i Konstantinopel på 6oo-tallet. Han forfattet flere medisinske bøker, blant annet en sammenfatning av gjeldende 
kunnskap og praksis innen uroskopi, kalt Peri ouron (Om urin) (모). Verket fikk stor utbredelse i den antikke verden og kom etter hvert til å utgjøre et viktig grunnlag for ideen om at urinen gjenspeiler kroppens indre.

Høydepunktet innen bysantinsk medisin kan sies å være representert ved Johannes, sønn av Zacharias, med tilnavnet Actuarius, som antas å ha levd ca. 1275-1328 (9.). Med sin egen versjon av Peri ouron videreførte han Theophilus' lære, men med betydelige utvidelser og presiseringer. I dette verket gir han nøyaktige anvisninger på hvordan urinprøven skal samles og overføres til en matula, en særlig utformet beholder med avrundet bunn, som må være laget av tynt og fargeløst glass av beste kvalitet. Han beskriver hvordan den må

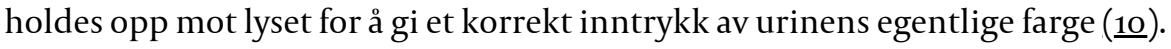

Johannes Actuarius skilte mellom ni grunnleggende farger, som hver kan forekomme i lysere og mørkere varianter. Fargen blir mørkere dersom kroppen produserer og skiller ut unormale substanser, mens lysere urin tyder på en svakhet i kroppen som gjør at de normale produktene ikke dannes eller at nyrene ikke klarer å skille dem ut. Han forklarte at en urinprøve skiller seg i tre ulike deler som må vurderes hver for seg. Det som synker ned mot bunnen av matula, kalles hypostases (med det tilsvarende latinske begrepet sedimentum). I den midtre delen finner man enceoremata (sublimia), mens vi helt øverst finner nubes (eller nubecula). For å gjøre undersøkelsen ytterligere detaljert må disse områdene igjen deles i til sammen 11 nivåer (fig 1$)$ (11). 


\section{DE DIFFERENTIIS feriorum fít fextus. Nanç quintũ $\&$ nonũ digitum nõ occuparunt un côtenta, Sưt ením terminatiōes po.}

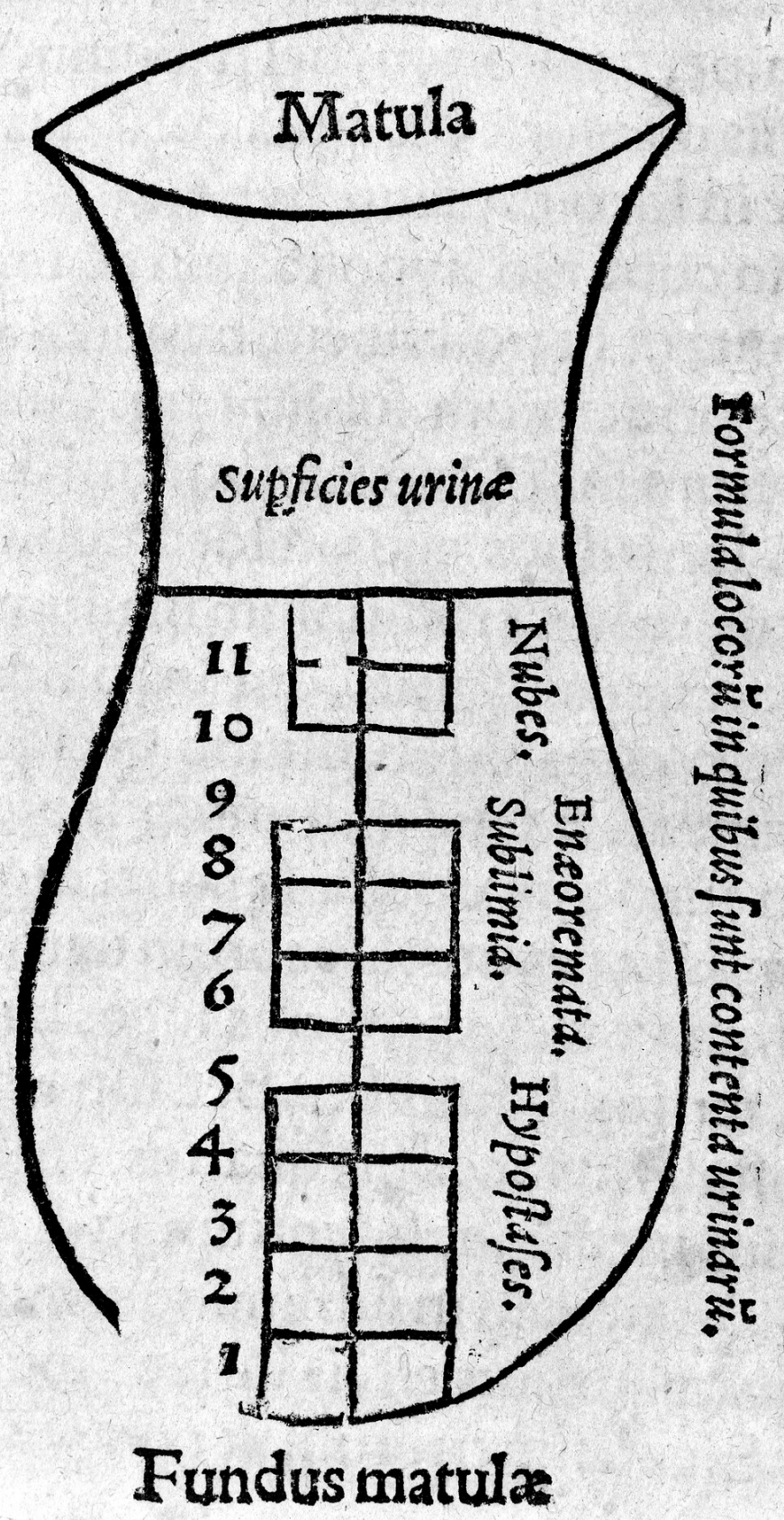

Figur 1 Den ideelle matula slik den er fremstilt i Johannes Actuarius' «De urinis». Foto: Wellcome Collection / Wellcome Library, London (CC BY 4.0)

Selv om Actuarius viser stor tiltro til urinunders $ø$ kelsen, understreker han at urinen normalt varierer med faktorer som alder og kjønn, kosthold og fysisk aktivitet. Urinfunnene må alltid ses i sammenheng med undersøkelsen av pasienten for øvrig, noe som krever både medisinsk kunnskap og menneskekunnskap. 
I høymiddelalderen flyttet det kulturelle og vitenskapelige tyngdepunktet vestover, i takt med det bysantinske keiserdømmets $\emptyset$ konomiske og politiske tilbakegang. Men de greske skriftene ble oversatt og utgjorde et viktig grunnlag for praksis og undervisning.

En av de mest prestisjefylte medisinske skolene i Europa på 110o- og 1200-tallet lå i Salerno i Sør-Italia. Det mest kjente, originale uttrykket for den salernitanske medisinen er helsediktet Regimen sanitatis salernitanum, også kalt «Flos medicinae» (Medisinens blomst), utgitt i navnet til Arnaldus de Villanova Cathellano. Teksten er skrevet i heksameter og med enderim. Dette gjorde at det var lett å lære utenat og derfor egnet seg godt som tekst for studenter. Dette har nok bidratt til at det fikk en overveldende popularitet og ble oversatt

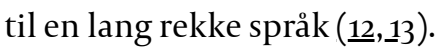

Urinundersøkelse ble holdt høyt i hevd i Salerno, og kunnskap om denne metoden utgjorde en viktig del av pensum for de kommende medisinere. Gilles de Corbeil, som senere ble kannik i Paris og livlege for kong Philippe-Auguste, studerte og underviste i Salerno. For å gjøre stoffet lettere å huske for studentene, overførte han deler av det til vers, med rytme og rim. Han skrev således et dikt på 352 vers om urin, basert på Theophilus' avhandling (14.). Også dette diktet ble svært populært og fikk stor utbredelse.

Som hjelpemiddel for den praktiske utøver av uroskopi ble det på denne tiden laget bildefremstillinger med plansjer og figurer som forklarte hvordan ulike farger og andre egenskaper ved urinen skulle vurderes og fortolkes, typisk med 20 forskjellige fargenyanser (fig 2) (15). Urinens lukt og smak var også med i vurderingen (므).

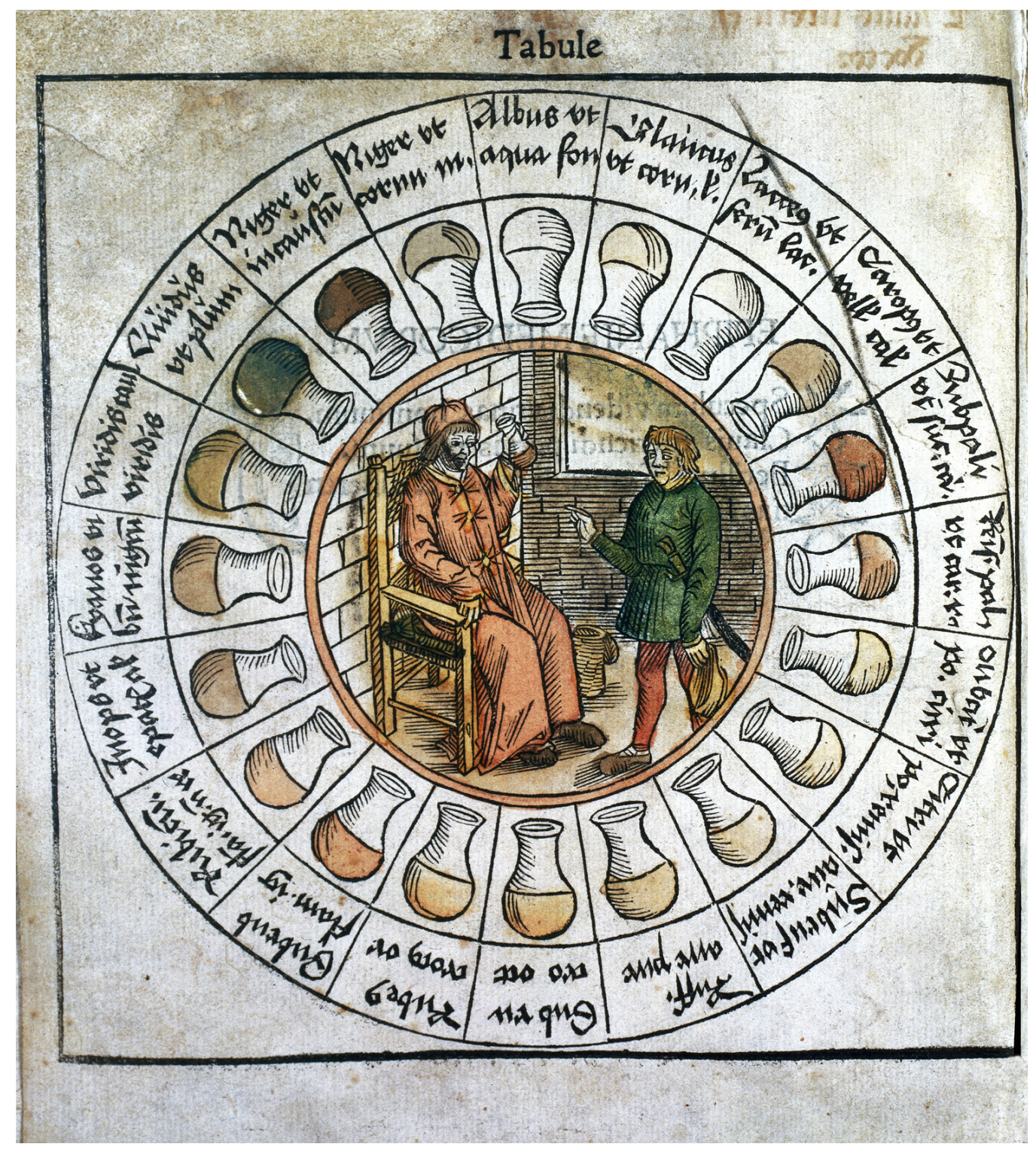


Figur 2 Det såkalte urinhjulet, med en fargeskala som får en til å tenke på moderne urinstiks. Foto: Wellcome Collection / Wellcome Library, London (CC BY 4.0)

Etter hvert fikk uroskopien status som legenes viktigste diagnostiske redskap, noe som representerte et brudd med den antikke tradisjonen, hvor anamnesen og klinisk

undersøkelse var viktigere. Uroskopi ble selve innbegrepet av medisinsk praksis, og matulaen ble det ikoniske kjennetegnet på legen, omtrent som stetoskopet i våre dager. I tallrike kunstverk fra 1500- og 16oo-tallet er legen avbildet mens han tankefullt studerer dette symbolsk viktige instrumentet (fig 3) (17.).

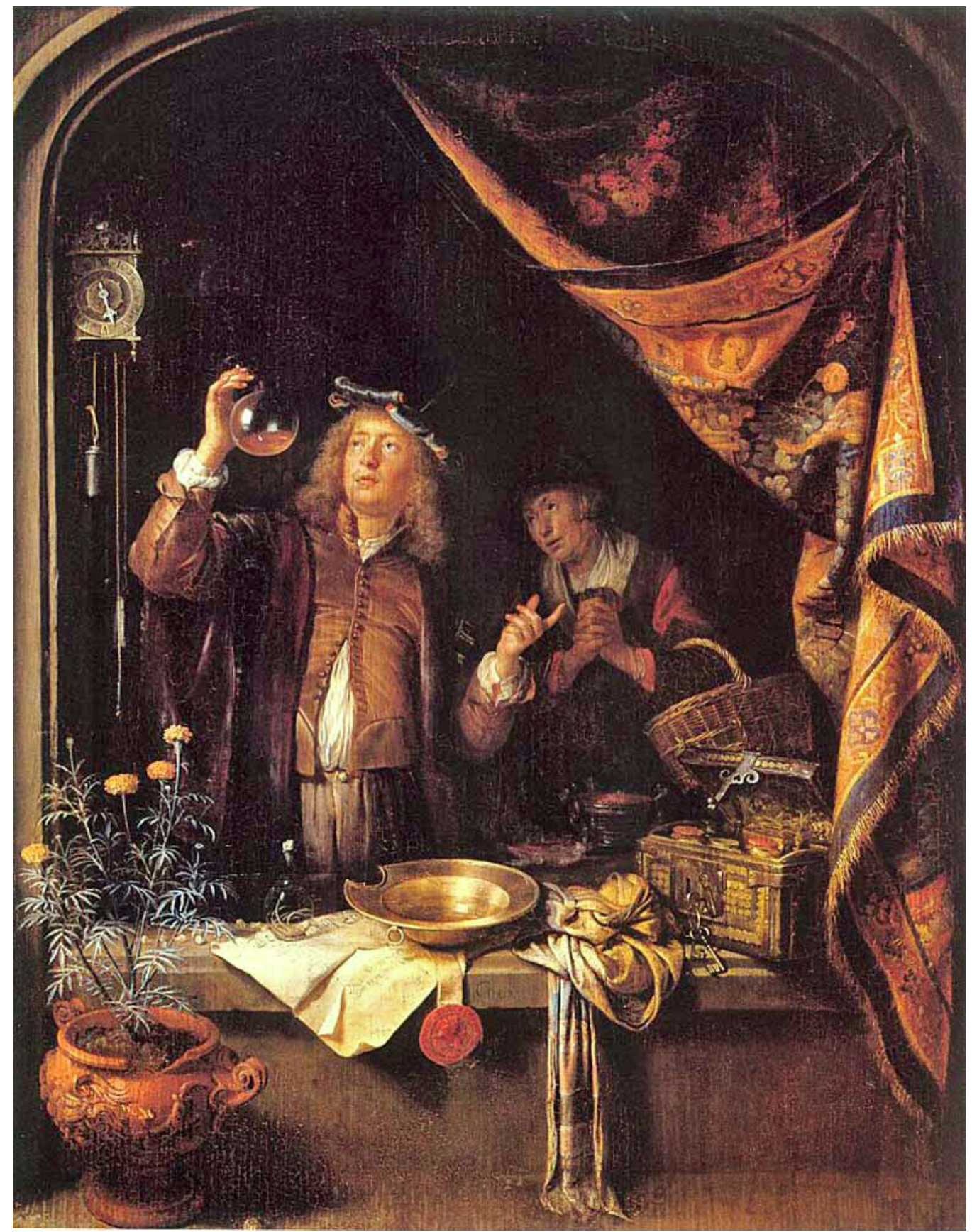

Figur 3 Gerrit Dou (1613-1675). «En lege studerer urin». Foto: Statens Museum for Kunst, København

\section{Uroskopi i Skandinavia}

I Skandinavia var uroskopi antagelig lenge kun kjent blant noen få, internasjonalt orienterte medisinere, som riktignok ikke brukte uroskopi i egen praksis. Verken den første trykte medisinske teksten på dansk fra 1533, Christiern Pedersens Lagebog, eller 
tilsvarende tekster publisert på latin fra samme periode av fremtredende danske medisinere nevner uroskopi.

Først i 1557 blir uroskopi omtalt på et nordisk språk, i Henrick Smits En liden Bog om Menniskens Vand och anden naturlig Affgang (fig 4) (묘,19). Ut fra Smits fremstilling kan det synes som om uroskopien er noe nytt i Danmark, og han gir en komplett, systematisk introduksjon til emnet. De medisinske bøkene hans ble svært populære, de ble trykt i flere opplag og spredt til resten av Skandinavia. Uroskopien synes likevel å ha fått mindre betydning på våre breddegrader enn andre steder, muligens fordi den ble introdusert sent og ikke ble fremmet av medisinere som var tilstrekkelig innflytelsesrike (19.).

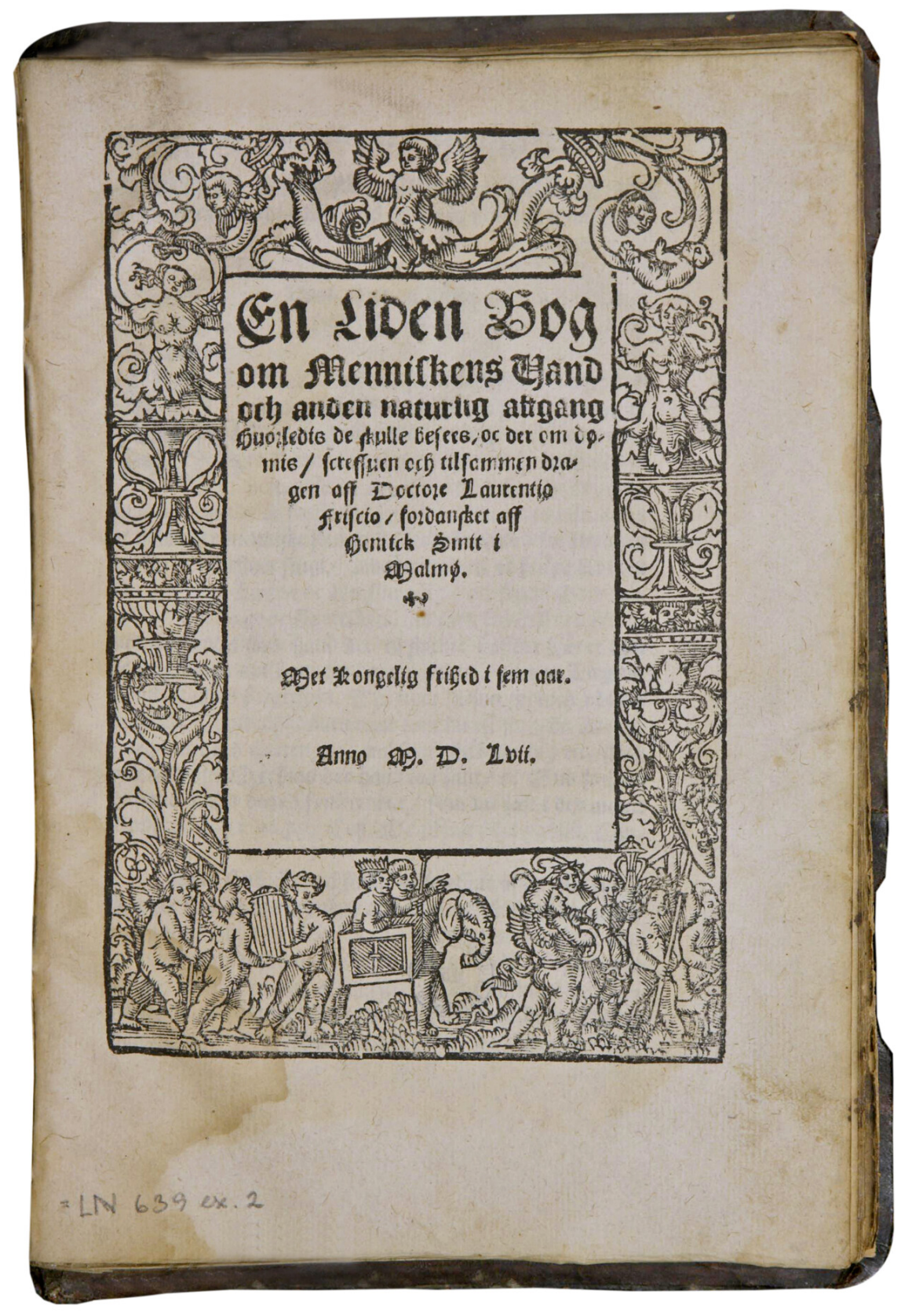

Figur 4 Henrick Smit. En liden Bog om Menniskens Vand och anden naturlig Affgang, 1557. Foto: Det Kongelige Bibliotek, København / ProQuest

\section{Leger og sjarlataner}


I andre land stolte noen leger etter hvert så mye på urinundersøkelsen at de foretrakk å studere en urinprøve fremfor å undersøke pasienten. En gjennomgang av tyske legers egne beretninger og av brev de har mottatt fra pasienter, tyder på at allmuens omseggripende tiltro til uroskopien har vært medvirkende til at mange leger etter hvert følte seg tvunget inn i en praksis med å uttale seg om pasientenes helsetilstand kun ut fra inspeksjon av en urinprøve (20)$)$.

Men det manglet ikke på skeptikere, og noen forsøkte å latterliggjøre fenomenet. I Dekameronen forteller Boccaccio om Bruno, som innbiller den uintelligente Calandrino at han er syk (1ㅡ): «Jeg synes du skal gå til sengs og trekke dynen godt om deg, og så må du sende tegnet ditt [urinprøven] til mester Simon [legen], som du vet vi bruker å gjøre i slike tilfeller» (egen oversettelse fra italiensk).

Med økende popularitet ble kunsten å vurdere urinprøver tatt opp av og også utøvd av andre enn skolerte medisinere. Det vokste frem en egen profesjon av mer og mindre seriøse uroskopister, som tok imot og tolket tilsendte og tilbrakte prøver og stilte diagnoser og kom med prognoser. Etter hvert dukket det opp omreisende spåmenn og sannsigere som $\mathrm{i}$ en urinprøve kunne lese ikke bare folks nåværende helsetilstand, men også deres

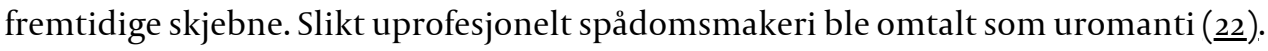

Enkelte medisinere advarte mot den sterke troen på urinundersøkelsen. Dels ville man avsløre vrangforestillinger og overtro, dels beskytte sin egen profesjon mot konkurranse fra amatører og humbugmakere (23-25).

\section{Urin og alkymi}

Urin var i mange år et yndet utgangspunkt for alkymistenes bestrebelser på å lage gull. Det kunne muligens skyldes den gule fargen, som kunne minne om det edle metallet og dermed allerede hadde noen av gullets egenskaper. Selv om ingen av dem klarte å lage gull ved hjelp av urin, fikk den tyske alkymisten Hennig Brand æren av å ha oppdaget fosfor $\mathrm{i}$ $1669(\underline{26})$. Han kokte urin til en tykk grøt, som han deretter destillerte. Dermed fikk han et fast, hvitt stoff, som glødet blågrønt i mørket og lett kunne antennes. Dette stoffet ble kalt "phosphorus mirabilis», "vidunderlig lysbærer». Det ble senere klart at det dreide seg om et nytt grunnstoff, det første nye i tillegg til de 12 som hadde vært kjent allerede i antikken.

I de neste årene skjedde store vitenskapelige fremskritt, både teoretisk og praktisk. Allerede på 150o-tallet hadde Paracelsus forkastet den antikke humoralpatologien og foreslo at sykdom skyldtes giftstoffer i kroppen, som blant annet kunne merkes på endret sammensetning i urinen. Han slo til lyd for en medisin basert på kjemisk kunnskap og mente at legemidler burde inneholde enkle og rene kjemiske substanser, ikke bestå av mange ingredienser (207.).

De nye tankene vant lite gehør i starten, og det medisinske fakultetet i Paris gikk så langt som til å forby sine medlemmer å forskrive kjemisk baserte legemidler. Men gradvis ble den moderne kjemien til, og med utvikling av nye målemetoder kunne fysiske egenskaper ved urinen måles.

I Belgia studerte Jan Baptista van Helmont (1579-1644) urinens spesifikke vekt og satte tettheten i sammenheng med vanninntaket. Nederlenderen Herman Boerhaave (1668-1738) gjorde systematiske urinunders $\emptyset$ kelser med kjemiske metoder $(\underline{28})$. På 170o-tallet ble urea identifisert, og etter hvert ble andre stoffer isolert fra urinen. I England så Robert Hooke (1635-1703) på urinprøver i mikroskopet, og i 1665 beskrev han krystallinske partikler i urinsedimentet i sin Micrographia (29.).

\section{En ny tid}


Med den nye innsikten i fysiske og kjemiske fenomener ble det vanskelig å få de nye oppdagelsene til å passe med den gamle kraselæren. En som sto med én fot i hver leir, og som måtte gå til store intellektuelle anstrengelser i sine fors $\emptyset \mathrm{k}$ på å få de to systemene til å henge sammen, var Joseph Loew (30). I sin bok fra 1815 refererer han til den nye viten om urinens kjemiske sammensetning og prøver å innpasse denne i en humoralpatologisk og vitalistisk forståelsesramme.

Resultatet virker unektelig nokså fremmed og inkonsistent for oss i dag. Når han forklarer hvordan urinen gradvis endrer utseende hos en pasient med langvarig febersykdom, bruker han dels uttrykk hentet fra den tusenårgamle uroskopien, dels begrep fra moderne kjemi: «Jo mer feberen nærmer seg sitt toppunkt og ved sin kraftige aktivitet i organismen på alle måter viser sin nær forestående fullendelse og sin egentlige natur, desto mer øker urinens turbiditet, og utfellingen av de ulike naturkvaliteter begynner med dannelsen av sedimenter. Utfellingen begynner vanligvis helt øverst i form av en sky (nubecula), som består av økt mengde gelatin og albumin, sammen med suspendert urinsyre og noe kalkfosfat. Når skyen senker seg mot midten [av glasset], blir den til enaeorema, og til slutt går den over i sedimentum» (egen oversettelse fra tysk).

Først med Rudolph Virchows banebrytende arbeid med histologiske unders $\emptyset$ kelser av vevsprøver fra syke mennesker, mistet humoralpatologien og kraselæren definitivt sin posisjon i vestlig medisin (31). Cellulærpatologien, forståelsen av sykdom som uttrykk for kjemiske og morfologiske forandringer i kroppens celler, ble dominerende. Utover på 180otallet ble urinmikroskopi en viktig teknikk, av stor betydning for diagnostikk av infeksjoner og andre betennelsesprosesser i nyrene og urinveiene, senere også cytologisk undersøkelse med tanke på svulstsykdommer. Mens den gamle uroskopien ble irrelevant, fikk begrepet ny betydning, nå i form av uromikroskopi.

I dag brukes stort sett teststrimler for å undersøke innholdet av kjemiske substanser i urinen, og mikroskopiens rolle er mindre enn den var for noen tiår siden. Men kanskje kan situasjonen komme til å endre seg. I 1980-årene oppdaget forskere at celler skiller ut membranbundne vesikler, med diameter helt ned mot $150 \mathrm{~nm}$ - eller enda mindre - som man må bruke elektronmikroskop for å se. Til å begynne med vakte funnet liten oppmerksomhet, og man antok det dreide seg om utskilling av unyttige komponenter.

I løpet av det siste tiåret har imidlertid interessen for slike eksosomer økt voldsomt (322). Det ser ut til at de aller fleste celler produserer partikler av denne typen. De inneholder både proteiner, lipider og nukleinsyrer, blant annet regulatorisk RNA.

Det viser seg at vesikler som skilles ut av én celle, kan tas opp av andre. Dermed kan informasjon overføres mellom celler, sannsynligvis som ledd i et intercellulært kommunikasjonssystem av en tidligere ukjent type. Vesiklene kan isoleres fra blod, men finnes også i mange andre kroppsvæsker, inkludert urin. Disse er i dag spennende kandidater for nye biomarkører for sykdom. Kanskje kan slike mikrovesikler gi urinen fornyet interesse i diagnostikken, slik at vi nok en gang kan oppleve at uroskopibegrepet får nytt innhold og ny betydning?

\section{LITTERATUR}

1. British Medical Association. The Evolution of Urine Analysis. An Historical Sketch of the Clinical Examination of Urine. Lecture Memoranda. Birmingham: Burroughs Wellcome \& Co, 1911.

2. Humoralpatologi. https://sml.snl.no/humoralpatologi (18.7.2016).

3. Carstens S. Humoralpatologisk medisin. Michael 2014; 11:101-12.

4. Uroskopi. I: Hødnebø F, red. Kulturhistorisk leksikon for nordisk middelalder fra vikingtid til reformasjonstid. Oslo: Gyldendal, 1975:360-1.

5. Lister M. Hippocratis Aphorismi, cum Commentariolo. Tübingen: Carol. Theophil. Ebertum, 1730.

6. Moulinier-Brogi L. L’Uroscopie au Moyen-Âge. Paris: Honoré Champion, 2012. 
7. Vlahakos D, Drakou A, Marathias Ket al. Some errors, under the light of the current knowledge, in the ideas of Hippocrates, Aristotle and Galen on renal physiology. J Nephrol 2013; 26 (suppl 22 ): 217 - 25.

8. Smith W. A new classical dictionary of biography, mythology, and geography. 2. utg. London: Murray, 1853 .

9. Diamandopoulos AA. Joannes Zacharias Actuarius. A witness of late Byzantine uroscopy, closely linked with Thessaloniki. Nephrol Dial Transplant 2001; 16 (suppl 6): 2 - 3. [PubMed][CrossRef]

10. Actuarius J. De urinis (oversettelse til latin ved Ambrosius Leo Nolanus, 1519). Basel: And. Cratandrum, 1709. Early European Books. https://archive.org/details/early-european-books (2.7.2016).

11. De Urinis. London: Wellcome Library. https://wellcomeimages.org/ (23.10.2016).

12. De conservanda bona valetudine, opusculum scholæ Salernitanæ. Novissimè impressis, \& auctis. Venezia: Ioan. Curionem, 1587.

13. Reichborn-Kjennerud I. Helsediktet fra Salerno: Latinsk tekst og norske vers. Halden: E. Sems forlag, 1932. Nasjonalbibioteket. https://www.nb.no/(7.7.2016).

14. Eugène-Humbert G. L'examen des urines à travers les siècles. I: Barraud G. Histoire de la médecine, 1952. Rev Hist Pharm (Paris) 1953; 41: 138.

15. Epiphaniae medicorum, uroscopy and ring of flasks. London: Wellcome Library. https://wellcomeimages.org/(23.10. 2016).

16. Myren-Svelstad S, Halgunset J. Urin har vært brukt til så mangt. Tidsskr Nor Legeforen 2017; 137: 10.4045/tidsskr.17.0323. [PubMed][CrossRef]

17. A Doctor Examining Urine. The Athenaeum. http://www.the-athenaeum.org/art/detail.php? $\mathrm{ID}=133529$ (22.10.2016).

18. Smit H. En liden Bog om Menniskens Vand och anden naturlig Affgang. København: Hans Vingaard, 1557. Early European Books. https://archive.org/details/early-european-books (13.9.2015).

19. Jungersen K. Reception of uroscopy in Scandinavia. J Nephrol 20o9; 22 (suppl 14): 50 - 4. [PubMed]

20. Stolberg M. Uroscopy in Early Modern Europe. Engelsk oversettelse. New York: Routledge, 2016.

21. Boccaccio G. Decamerone. Venezia: Giovanni \& Gregorio de Gregorii fratelli, 1492. Fondazione BEIC [Biblioteca Europea di Informazione e Cultura. http://www.beic.it/it/articoli/biblioteca-digitale (2.7.2016).

22. Cardini M. Uroscopia, uromanzia ed uromania nel passato. Milano: Proveinaze Midy, No 6, 1935.

23. Nöske HD. Der "Pisse-Prophet" oder "der englische Wahrsager aus dem Urin". Ein kritisches Buch zur Harnschau von Thomas Brian. Urologe A 2005; 44: 1062 - 3. [PubMed][CrossRef]

24. Hornung J. De uroscopia fraudulenta discursus. Kurzer Bericht von dem unvolkommenen und betrüglichen Urtheil des Menschlichen borns/oder harns: Cassenelnbogen, 1611. Faksimile-Druck. Lindau: Antiqua-Verlag, 1979.

25. Brian T. The Pisse-prophet or certaine pisse pot lectures. London: E.P., 1637. Early English Books Online. http://eebo.chadwyck.com/ (7.7.2016).

26. Verma S. The Little Book of Beginnings and Breakthroughs in Science. New Delhi: Orient Publishing, 2015.

27. Steiner L. Paracelsus and his influence on chemistry and medicine. Chambersburg, Pennsylvania: Kieffer and Co, 1853. U.S. National Library of Medicine, Digital Collections.

https://collections.nlm.nih.gov/ (29.3.2017).

28. Martin M, Fangerau H. Historische Umbrüche in der Harndiagnostik und ihre Visualisierung in "Frames". Urologe A 2006; 45: 742 - 8. [PubMed][CrossRef]

29. Eknoyan G. Looking at the urine: the renaissance of an unbroken tradition. Am J Kidney Dis 2007; 49: 865 - 72. [PubMed][CrossRef]

30. Loew J. Über den Urin als diagnostisches und prognostisches Zeichen in physiologischer und pathologischer Hinsicht. Landshut: Joseph Thomann, 1815. The Medical Heritage Library. https://archive.org/(30.6.2016).

31. Virchow R. Die Cellularpathologie in ihrer Begründung auf physiologische und pathologische Gewebelehre. Zweite Auflage. Berlin: August Hirschwald, 1859.

32. Théry C. Exosomes: secreted vesicles and intercellular communications. F10oo Biol Rep 2011; 3: 15. [PubMed][CrossRef]

Publisert: 19. mars 2018. Tidsskr Nor Legeforen. DOI: 10.4045/tidsskr.17.0322 
Mottatt 1.4.2017, første revisjon innsendt 27.9.2017, godkjent 13.12.2017.

(C) Tidsskrift for Den norske legeforening 2023. Lastet ned fra tidsskriftet.no 26. april 2023. 